\title{
SELF MANAGEMENT EXPERIENCE ON PATIENTS WITH HYPERTENSION IN PANGGANG ॥ COMMUNITY HEALTH CENTERS GUNUNGKIDUL DISTRICT
}

\author{
Andri Setyorini'), Niken Setyaningrum $\left.{ }^{2}\right)$ \\ ${ }^{1,2)}$ STIKES Surya Global Yogyakarta \\ Corresponding email: andrisetyo04@gmail.com
}

\begin{abstract}
BACKGROUND : Hypertension is a non-communicable disease that causes the highest death in the world. It is said hypertension if systolic pressure is $\geq 140 \mathrm{mmHg}$ or more and diastolic $90 \mathrm{mmHg}$ or more. National hypertension prevalence in the results of Basic Health Research (Riskesdas) in 2013 based on the results of blood pressure measurements by medical personnel reached $25.8 \%$. Selfmanagement activities, especially in patients with hypertension can certainly affect the possibility of complications and the degree of health of these patients. This study aims to find a picture related to the Self Management Experience in Patients with Hypertension.

SUBJECT AND METHODES : This study uses a qualitative descriptive approach with in-depth interviews, participant observation and documentation. Data analysis in this study used qualitative content analysis to interpret the description of data obtained from all interviews conducted with participants regarding self management experiences in patients with hypertension.

RESULTS : The results showed 4 main themes which were further described by researchers in the results of this study. The 5 themes are: 1) dietary patterns at home; 2) exercise routine; 3) antihypertensive drug therapy; 4) obstacles in controlling blood pressure; 5) source of support.

DISCUSSION : With this research it is hoped that the prolanis program manager can design health education programs for hypertensive patients routinely and continuously in every event created, so as to increase patient awareness in carrying out proper self-care management.
\end{abstract}

Keywords: Self Management Experience, Hypertension

\section{INTRODUCTION}

Non-communicable diseases that cause the highest death in the world, one of which is hypertension. One non-communicable disease that causes the highest death in the world is cardiovascular disease, where the high mortality rate in cardiovascular disease is caused by the main risk factor, namely an increase in blood pressure (hypertension). An increase in a person's blood pressure will increase the risk of stroke and coronary heart disease (WHO, 2011).

Hypertension is better known as high blood pressure. The blood pressure limit that can be used as a reference to determine whether or not the blood pressure is normal is systolic and diastolic. Based on JNC (Joint National Committee) VII, a person is said to have hypertension if systolic pressure is 
$\geq 140 \mathrm{mmHg}$ or more and diastolic $90 \mathrm{mmHg}$ or more. Based on the etiology, hypertension can be divided into 2, namely essential hypertension and secondary hypertension.

Essential or idiopathic hypertension is hypertension without clear pathological basis. More than $90 \%$ of cases are essential hypertension. Causes of hypertension include genetic and environmental factors. While secondary hypertension covers $5-10 \%$ of cases of hypertension is secondary hypertension from comorbid diseases or certain medications that can increase blood pressure (Smeltzer \& Bare, 2001). In Indonesia, the national prevalence of hypertension in the results of the 2013 Basic Health Research (Riskesdas) based on the results of blood pressure measurements by medical personnel reached $25.8 \%$.

According to PERKI (2015) leading a healthy lifestyle has been shown to reduce blood pressure, and in general is very beneficial in reducing the risk of cardiovascular problems. In patients suffering from first-degree hypertension, without other cardiovascular risk factors, the healthy lifestyle strategy is an initial management stage, which must be undertaken for at least 4-6 months. If after this time period, there is no expected decrease in blood pressure or other cardiovascular risk factors are obtained, then it is highly recommended to start pharmacological therapy.

Nwinee (2011) explains that self care management is everything related to the client's responsibility in managing himself at home properly when there are no doctors and nurses. Self Care Management which is a form of hypertension patient behavior in managing hypertension is influenced by internal factors (from the patient's own) and external factors, namely from the environment in this case related to social support received by hypertensive patients in the management of hypertension. Contents Hypertensive self-management activities include: Weight reduction / control, reducing salt intake. exercise, reduce alcohol consumption, and stop smoking. Self-care management is a major factor in efforts to improve health. The ability of patients to meet self-care is influenced by internal and external factors (Orem, 2001). Self-management activities, especially in patients with hypertension can certainly affect the possibility of complications and the degree of health of these patients (Leventhal, Nerenz, \& Steele, in Taylor, 2006). Based on this description, researchers are interested in exploring self-management experiences in patients with hypertension in order to know how the picture is related to "Self Management Experiences in Patients with Hypertension?"

\section{METHODS}

This study uses a qualitative descriptive approach with in-depth interviews and observation as data collection methods (Sandelowski, 2009;Creswell, 2014). The study was conducted by directly describing and not manipulating the phenomena that occur regarding Illness Representation and Self Management Experiences in Patients with Hypertension in Baked II Health Center Gunungkidul.

Data analysis on a qualitative approach is subjective because the researcher is the main instrument for data collection and analysis of research (Creswell, 2014). Data analysis uses qualitative 
content analysis to interpret the description of data obtained from all interviews in hypertensive patients related to the description of Self Management Experiences in Patients with Hypertension.

\section{RESULTS}

This research was conducted to 7 participants through a process of in-depth interviews (in depth interviews) and then verbatim results were analyzed in order to obtain 4 main themes which were further described by researchers in the results of this study. The 5 themes are: 1) dietary patterns at home; 2) exercise routine; 3) antihypertensive drug therapy; 4) obstacles in controlling blood pressure; and 5) sources of support.

\section{Diet at Home}

Based on the results of research that has been done that most of the participants said that they had to reduce salt in every processing and daily consumption of food to control blood pressure so as not to be high.

“...sampai sekarang itu saya kalau masak tidak banyak garam" ("... until now, I don't cook too much salt") (P1, 69 years old, junior high school)

"sik pun dilakoni nggih niku kurangi garam carane nggih mangkih nek teng nggriyo masak dikurangi garame" ("what has been done is reducing the salt by means of cooking at home is reduce salt") ( $P 2,57$ years old, elementary school); ( $P 4,71$ years old, elementary school)

In addition to reducing salt in the implementation of the diet there are also participants who say that it must reduce oil because of the source of cholesterol.

"Pantangan onten sik liyane garam nggih minyak nggih gorengan barang niku soale niku kolesterol jare"( abstinence is there other than salt oil, fried food because it's said cholesterol) ( $P 2,57$ years old, elementary school)

"...kulo tahu tempe diabcem. mboten nate digoreng. Riyin digoreng ning sakniki ken ngirangi lingsah niku to bu gek pun mboten digoreng" (I never fried tempe or tahu, but it was fried in the past but now I am told to reduce the uterine oil, I have not fried it again) (P4, 71 years old, elementary school)

In this study the data obtained that almost all participants said that they began to reduce consumption of rice and coffee because according to them it can also increase blood pressure.

"Selain garam nggih niku kurangi kurangi nasi, banyak sayuran" ("In addition to salt, reduce rice, lots of vegetables") (P2, 57 years old, elementary school) (P4, 71 years old, elementary 
school); (P5, 54 years old, elementary school) (P6, 65 years old, elementary school); (P7, 80 years old, no school)

“..terus sudah tidak minum kopi”("... continue to not drink coffee") (P1, 69 years old, junior high school)

"Ngunjukke enjing teh manis kalih putih niku. Kopi sekali-kali kalau kepingin mawon" ("...drink it in the morning sweet tea and water, Coffee if just I want it") (P3, 61 years old, elementary school)

In implementing their daily dietary patterns they also say that they routinely consume vegetables and sometimes also with fruit because they follow the advice of doctors at the health center.

"Sekarang ya mung sayur-sayuran sayur bening ngoten niku dan kadang kalau ada juga buah"

("Now maybe the vegetables addict and sometimes if there is also fruit") (P1, 69 years old, junior high school); (P7, 80 years old, no school)

\section{Sports Routines}

In this study the next theme that emerged in the implementation of self management in patients with hypertension was related to sports routines, where almost all participants had exercised, namely gymnastics once a week at the health center, but not all of them routinely followed by reason of bother, no time, and etc.

"lya senam seminggu sekali dipuskesmas"("Yes gymnastics once a week at the community health center") (P1, 69 years old, junior high school)

"Olah ragane nek mboten repot nggih mangkat senam teng puskesmas" "if the exercise is not busy I go to gymnastics at the health center) (P2, 57 years old, elementary school); (P6, 65 years old, elementary school)

\section{Antihypertensive Drug Therapy}

Based on the results of the study all participants explained about the consumption of antihyertency drugs related to the type and dose of the drug. Where there are those who get 1 kind of antihypertensive medication and there are those who get 2 kinds of scaligus antihypertensive drugs at a dose once a day and some are 2 times a day.

"Nek obat tensi amlodipine kadang captopril ngambile sebulan sekali le ngunjuk sepindah pas enjing" "if the drug is tension amplodipine and sometimes captopril, take it once a month and drink it once in the morning") (P1, 69 years old, junior high school); (P3, 61 years old, elementary school); (P4, 71 years old, elementary school); (P6, 65 years old, elementary school); (P7, 80 years old, no school) 
"Obate amplodipin kalih sik kecil-kecil niku (captopril) sejak awal sudah 2 obat itu" ("the drug is amplodipine and the small ones (captopril) since the beginning have 2 drugs)") (P2, 57 years old, elementary school); (P5, 54 years old, elementary school)

\section{Obstacles In Controlling Blood Pressure}

Based on data collected from hypertensive participants experiencing several obstacles in controlling blood pressure at home, the first perceived obstacle concerns difficulties in terms of diet especially to reduce salt and oily food.

"Iha nek kurang garam niku mboten enak je.. .kurangi minyak juga tapi mboten saged (sambil tertawa)" (lack of salt is not good ... reduces the oil too but it is difficult (while laughing)) (P2, 57 years old, elementary school)

"Masak nggih serba minyak, gereh gek kanmongko seneng" ("I cook all the oil, salted fish I also really like) (P3, 61 years, elementary school); (P6, 65 years old, elementary school)

Next is the difficulty in participating in sports because of the perceived lack of time and difficulty in getting enough rest because some patients find it difficult to sleep and rest because some are still working.

"Olah raga niku waah..jarang olah raga mbak..Iha wedale niku Iho.." (sambil tertawa) (sports are seldom if not busy ...) (P5, 54 years old, elementary school); (P7, 80 years old, no school)

"..niku sakpangertosan kulo ning sik angel ki nggih ngaso (sambil tertawa)" (... to my knowledge but the hard ones are resting) (P4, 71 years old, elementary school)

"Kulo ki sok angel sanget tilem e mbak.." .. "(I was acting really hard to sleep like this) (P6, 65 th, elementary school); (P6, 65 years old, elementary school)

\section{Sources of Support}

Based on data collected from participants undergoing treatment at their home, they received external support in controlling blood pressure at home, such external support included support from family members.

"Kulo ki kiyambak teng nggriyo ning sedherek kiwo tengen niko gemati sanget kok" (I am alone at home but relatives who live right next to the left are very considerate) (P4, 71 years old, elementary school)

Other support comes from health services, namely from community health centers and clinics

"Nek priksa nggih ngantos sakniki nggih cocokke teng puskesmas niki mbak pun mboten pindah-pindah" (I have checked up to now so that it is suitable in this community health center not to move) (P6, 65 years old, elementary school) 
“...terus kolo wingi jumat wingi dipriksakken di klinik wonten Blimbing (nama klinik).." (Then, yesterday was examined at the Blimbing clinic) (P1, 69 years old, junior high school)

Furthermore, all participants said that other external support was also obtained from the health program that was followed, namely prolanis, and support from health financing guarantees namely BPJS.

"Kulo ndherek Prolanis niku pas wiwit onten prolanis pun ndherek skitar 2012 niku kulo" (I joined Prolanis since 2012) (P2, 57 years old, elementary school)

"Kami semua yang ikut prolanis menggunakan BPJS mbak..."

("All of us who joined the program using BPJS miss ...") (P1, 69 years old, SMP) (P3, 61 years old, elementary school); (P4, 71 years old, elementary school); (P6, 65 years old, elementary school); (P7, 80 years old, TS)

“...kulo BPJS mandiri iuran tiap bulan niko" (..saya BPJS mandiri iuran tiap bulan itu)(P2, 57 th, $S D) ;(P 5,54$ th, $S D)$

\section{DISCUSSION}

\section{Diet at Home}

Based on the results of research that has been done that most of the participants said that they must reduce salt in every processing and consumption of daily food to control blood pressure so as not to be high. Restricting sodium consumption is an action to prevent an increase in blood pressure. Salt restriction is done by reducing the amount or dose of partispan daily salt so it does not really use salt at all (Elvi O, et al, 2018).

In addition to reducing salt in the implementation of the diet there are also participants who say that it must reduce oil and rice because according to them it can also increase blood pressure. In implementing their daily dietary patterns they also say that they routinely consume vegetables and sometimes also with fruit because they follow the advice of doctors at the health center. The importance of low-salt diet as explained by Puspita, et al (2012) explains that diet is one way to overcome hypertension without serious side effects because of its natural control methods. Reducing salt intake, increasing fiber, stopping bad habits such as smoking, drinking coffee, consuming alcohol, utilizing vegetables and herbs and taking medicine regularly will help in lowering blood pressure.

\section{Sports Routines}

Based on the results of this study, the next theme that emerged in the implementation of self management in patients with hypertension was related to sports routines, where almost all 
participants had done sports, namely gymnastics once a week at the health center, although not all routinely follow for various reasons. The importance of physical activity is because physical activity is an activity where carrying out daily activities is included in physical activity, besides physical activity is an activity that is cheap, easy and healthy because doing physical activity makes the blood pressure in systolic decrease by 4-9 mmHg (Paul A et al., 2015)

While the research of Surbakti (2014) explains that sports activities such as 30 minute walking exercises have an effect on the decrease in systolic blood pressure in patients with hypertension. This is due to aerobic forms of exercise such as walking exercises can influence in increasing blood capillaries, hemoglobin concentration, differences in oxygen in the arteries and veins and blood flow in the muscles.

\section{Antihypertensive Drug Therapy}

Based on the results of this study all participants delivered about antihypertensive drug therapy that has been undertaken, because all participants routinely consume antihypertensive drugs with different types and dosages for each participant, there are those who get just one type of drug, but there are some who get 2 types of antihypertensive drugs at the same time with the dosage and schedule of taking medication 1 time a day and some are 2 times a day.

Treatment of hypertension according to WHO (2012) aims to achieve rational use of medicines by referring to the use of responsible drugs which means patients receive the right medicines at the right time, use the right drugs and cause benefits to patients, so it is important have knowledge and awareness about treatment. The use of antihypertensive drugs in hypertensive patients includes the accuracy of the drug, the accuracy of the dose, and the patient's compliance in taking the drug Rakha. (2015). So that in this study all participants already knew about the use of drugs and drug doses taken.

\section{Obstacles in Blood Pressure Control}

Based on data collected from the experience of self management in participants with hypertension, they said that they experienced some obstacles in controlling blood pressure at home. The perceived obstacle is the first concerning the difficulty in terms of diet especially to reduce salt and oily food because they feel bad if the food is less salt and the habit of consuming fried foods which is also difficult to leave.

Other research that is in line with Prasetyo (2012) found that the elderly often found that their diet is still wrong where most elderly people still like salty and savory foods, especially fast foods that contain lots of saturated fats and high levels of salt so have a great chance of getting hypertension. This certainly affects the difficulty of someone in removing the habit if the daily food consumed is still the same as before going on a diet. Ideally the foods recommended in the DASH dietary guidelines consist of rice, side dishes, vegetables and fruits without salty taste when tasted and served (Azizah, 2011). By consuming the right and right foods can help the elderly in controlling blood pressure. 
Furthermore, the difficulties experienced by participants are in terms of participating in sports because of the perceived lack of time and difficulty in getting enough rest because some patients find it difficult to sleep and rest because some are still working. Johnson, Sheldon, and Carey (2010) who show that prolonged illness does not guarantee an increase in patient compliance in the selfmanagement process. Patients can seek information from various sources at the time of initial diagnosis of the disease and after that the patient does not get a structured education program according to the patient's condition, so that at the time of evaluation there is no increase in knowledge and meaningful behavior changes in these patients.

\section{Sources of Support}

Based on data collected from participants who are undergoing treatment at their home received external support in controlling blood pressure at home, the external support included support from the family. Family support obtained by patients in the treatment of hypertension at home is in the form of mental, information, instrumental and financial support (Elvi O, et al, 2018). Various verbal responses from the family are generally received by participants. This verbal response usually arises because it is triggered by a family fearing continuous high blood pressure and its effects. These effects are related to the condition of headache, palpitations, excessive anxiety and nervousness in the neck. This should be a concern of hypertension sufferers (Loriza S., et al, 2018).

Other support comes from health services namely and from the health program that is followed, namely prolanis, and support from health insurance, namely BPJS. The availability of health insurance makes it easy to pay so that access to health services such as routine blood pressure checks is easier to reach, compared to patients who do not have health insurance because frequent treatment will always be costly (Djuhaeni, 2007).

\section{CONCLUSION AND RECOMMENDATION}

The description of self management experiences in patients with hypertension is related to:

1. A description of dietary patterns at home where all participants know that they must reduce salt intake in their diet and also reduce oil and increase vegetables and fruit.

2. The description of sports routines carried out by participants is that most of them do routine exercise, namely gymnastics at the puskesmas although not all participants routinely attend these activities for various reasons.

3. All participants are routinely taking antihypertensive drugs with different types and doses of each participant, there are those who get just one type of drug, but there are some who get 2 types of antihypertensive drugs at once, with the dosage and schedule of taking drugs one time a day and there are also the 2 times a day. 
4. Obstacles in Blood Pressure Control experienced by participants, namely in terms of diet, especially in reducing salt and oily food, difficulty in participating in sports because of the time that is felt to be inappropriate and difficulty in adequate rest especially difficulty in terms of sleep.

5. All participants have sources of support obtained from external parties including support from families, support from health services and health programs that are followed, namely prolanis, and support from health insurance, namely BPJS.

From the result of study, some recommendation based in this study are :

1. For Hypertension Patients

It is recommended to further increase self-awareness in maintaining diet, especially in salt intake and oil consumption as well as increasing restitution so that blood pressure can be controlled properly.

2. For Families

It is recommended to always provide support, affection, attention, so that it can help the patient's healing process.

3. For community health centers and health services

For the puskesmas, especially the prolanis program manager, it is hoped that in the future they can design health management and education programs for hypertensive patients routinely in every event that is created so as to increase patient awareness in carrying out proper self-care management.

4. For Other Researchers

In order to conduct further research on coping strategies and self-regulation in the implementation of self-management in patients with hypertension.

\section{REFERENCE}

Azizah, L. M. R. (2011). Keperawatan lanjut usia. Yogyakarta : Graha llmu

Creswell John W. (2014). Penelitian Kualitatif \& Desain Riset. Yogayakarta: Pustaka Pelajar.

Djuhaeni, H. (2007). Asuransi Kesehatan dan Managed Care. Universitas Padjajaran.

Elvi O. Hayatunnupus H. Esi A. Studi Fenomenologi Tentang Pengalaman Pasien Hipertensi Terhadap Perawatan Dirinya Di Wilayah Kerja Puskesmas Andalas Padang Tahun 2017. Jurnal Keperawatan, Volume 14, No. 1, Maret 2018, (Hal. 1-10))

Johnson, T., Sheldon, \& Carey, P. (2010). Meta-synthesis of health behaviour change meta-analyses. American Journal of Public Health, 100(11), 2193-2198

JNC 8. (2015). Hypertension: the silent killer: updated JNC-8 guideline recommendations 2015. Diakses dari http://www.aparg.org.

Leventhal, H ., Diefenbach, M., \& Leventhal, E. A (1992). Illness cognition: Using common sense to Understand treatment adherence and affect cognition treatment. Cognitive Therapy and research, 16, (2), 143 - 163 
Loriza Sativa Yan, Fx. Suharto, Eridia. Pengalaman Diet Lansia Perempuan Penderita Hipertensi. Jurnal IImiah Keperawatan Indonesia. Vol 2, No 1, 2018 ISSN: 2580-3077 http://jurnal.umt.ac.id/index.php/jik/index 65

Orem, D. E., (2001). Nursing : Concept of practice. (6th Ed.). St. Louis : Mosby Inc.

Kemenkes. Riset Kesehatan Dasar: Riskesdas (2013) . Jakarta: Badan Penelitian dan Pengembangan Kesehatan Kementrian Kesehatan RI.

Nwinee, J.P. (2011). Socio-Behavioral Self-Care Management Nursing Model. West AfricanJournal of Nursing; 22:91- 98. 7 Agustus 2018 (08:00)

Paul A, J., Suzanne, O., Barry L, C., William, C. C., Cheryl Dennison, H., Joel, H., ... Eduardo, 0. (2015). JNC 8: Evidence-Based Guideline for the Management of High Blood Pressure in Adults in 2014. Bangladesh Journal of Medicine, 25(1), 1-2. https://doi.org/10.3329/bjmed.v25i1.25069

Perhimpunan Dokter Spesialis Kardiovaskuler Indonesia (PERKI). 2015. Pedoman Tatalaksana Gagal Jantung (edisi pertama). Jakarta: PERKI

Prasetyo, D. A. (2012). Faktor-faktor yang berhubungan dengan kejadian hipertensi pada usia dewasa muda di wilayah Puskesmas Sibela Surakarta. Diakses dari http://eprints.ums.ac.id/37940/2/HALAMAN\%20DEPAN.pdf

Puspita A., Aisah, S., dan Sutoyo (2012). Sikap Terhadap Kepatuhan Diit Hipertensi Dengan Tekanan Darah Pada Penderita Hipertensi Di Wilayah Kerja Puskesmas Doro II Kabupaten Pekalongan. Jurnal Fikkes keperawatan Vol. 5 No. 1 Maret 2012: 1 - 13

Rakha. (2015). Evaluasi penggunaan obat anthipertensi pada pasien hipertensi rawat jalan di puskesmas sempaja samarinda. Jurnal Sains dan Kesehatan. Vol 1. No 2. 82 ISSN: 2303-0267, e-ISSN: 2407-6082

Sandelowski M. (2000). Focus on Research Methods Whatever Happened to Qualitative Description. 23,334-340

Smeltzer, S. C., \& Bare, B. G. (2001). Buku Ajar Keperawatan Medikal-Bedah Brunner dan Suddarth Volume 2, Edisi 8. Terjemahan oleh Agung Waluyo, dkk. Jakarta: EGC

Surbakti.S. (2014). Pengaruh Latihan Jalan Kaki 30 Menit Terhadap Penurunan Tekanan Darah Pada Pasien Penderita Hipertendi Di Rumah Sakit Umum Kabanjahe . Jurnal Pengabdian Masyarakat Vol. 20 Nomor 77 Tahun XX September 2014

Taylor, S. E. 2006. Health Psychology. NMcGraw-Hill Companies, Inc, NewYork

World Health Organizatio. WHO Guideline; Hypertension. (2011). http://www.who.int/cardiovascular diseases/guidelines/hypertension/en/ diakses tanggal 30 September 2017.

WHO (2012). The Pursuit of Responsible Use of Medicines: Sharing and Learning from Country Experiences. Geneva: http://www.who.int/medicines/publications/responsible_use/en/index.html 